\title{
PENDIDIKAN UNTUK MEMECAHKAN MASALAH BANGSA MELALUI PENINGKATAN PROFESIONALISME GURU (Belajar dari Pengalaman Jepang)
}

\author{
Ary Purwantiningsih ${ }^{1}$, Pudjo Suharso ${ }^{2}$ dan Erik Aditia Ismaya ${ }^{3}$ \\ ${ }^{1}$ Universitas Terbuka, ${ }^{2}$ Universitas Jember, ${ }^{3}$ Universitas Muria Kudus \\ Email: arypurwanti490@.gmail.com; harsodit@yahoo.co.id; erik.aditia@umk.ac.id
}

\section{Info Artikel \\ Sejarah Artikel: \\ Diterima 6 Juni 2018 \\ Direvisi 26 Oktober 2018 \\ Disetujui 30 November 2018}

\section{Keywords:}

Proffesional Teacher, Education

Progress

\section{Abstract}

The purpose of this study is to analyze the efforts of the Japanese Government in solving educational problems after the second world war. The research method used is library research. The results of the study found that one of the advances in education in Japan was then used as an instrument to solve the nation's problems, namely through the improvement and development of professional teachers. By building professional teachers, Japan is now one of the mecca of the advancement of education from the East. Education in Japan is known as education on a philosophical basis of developers other than Taiwan, while Western world education is based on inventors.

\begin{abstract}
Abstrak
Tujuan penelitian ini yaitu menganalisis upaya Pemerintah Jepang dalam memecahkan persoalan pendidikan setelah perang dunia kedua. Metode penelitian yang dipergunakan yaitu riset kepustakaan (library research). Hasil penelitian menemukan bahwa salah satu kemajuan pendidikan di Jepang yang kemudian dijadikan instrumen untuk memecahkan problema bangsa yaitu melalui peningkatan dan pengembangan guru professional. Dengan membangun guru yang professional, saat ini Jepang menjadi salah satu kiblat kemajuan pendidikan dari Dunia Timur. Pendidikan di Jepang dikenal sebagai pendidikan dengan basis filosofis pengembang selain Taiwan, sementara pendidikan dunia Barat lebih banyak berbasis penemu.
\end{abstract}


Purwantiningsih, Ary., Suharso, Pudjo dan Ismaya, Erik Aditia

PENDIDIKAN UNTUK MEMECAHKAN MASALAH BANGSA MELALUI PENINGKATAN ... REFLEKSI EDUKATIKA : Jurnal Ilmiah Kependidikan, Nomor 9, Volume 1, Desember 2018, hlm. 26-32

\section{PENDAHULUAN}

Guru merupakan komponen sangat penting dalam pendidikan. Bahkan dapat dikatakan bahwa guru merupakan kunci paling strategis bagi pengembangan pendidikan berkualitas (Suyanto 2000). Begitu penting peran guru dalam pendidikan, tidak mengherankan apabila Kaisar Jepang Hirohito pada pasca kekalahan Jepang dari Sekutu menanyakan berapa jumlah guru yang masih hidup. Di pundak guru itulah Kaisar Hirohito meletakkan kepercayaannya untuk membangun kembali (rebuild) Jepang yang hancur melalui pendidikan dan berhasil.

Temuan Janes (2010) dan Harwell (2013) mengungkapkan bahwa kemajuan pendidikan di Jepang salah satunya terletak pada komitmen pemerintah Jepang untuk meningkatkan kualitas profesionalisme guru. Dengan membangun profesionalisme guru akan melahirkan pendidikan yang maju sebagai instrument untuk memecahkan masalah bangsa Jepang di abad 21 ini (Watanabe 2013).

Japan has been at or near the top of the international rankings on education. Japan may have achieved this consistent standing and what other countries might be able to learn from the Japanese experience. The Japanese education system is grounded in a deep commitment to teachers that is concrete and enduring. Japan's success to a first-rate teaching force, superb family support for Japanese students at home, the way resources are focused on instruction and the strong incentives the system provides for students to take tough courses and study hard in school (Janes 2010).

Temuan Janes, Harwell dan Watanabe tersebut memperlihatkan bukti bahwa untuk memecahkan masalah bangsa (Jepang) di masa mendatang melalui pendidikan dapat dilakukan melalui upaya membangun profesionalisme guru. Dalam menatap masa depan, Jepang saat ini dihadapkan dengan masalah perkembangan ilmu dan teknologi yang eksplosif yang menuntut respon dunia pendidikan untuk dikembangkan secara baik. Kurokawa (2014), mengatakan "standing at the beginning of the 21st century, Japan face the explosive growth of science, and technology". Kurokawa selanjutnya mengatakan salah satu komitmen pemerintah Jepang dalam merespon problem bangsa Jepang mengembangkan ilmu dan teknologi adalah membangun profesionalisme guru.

\section{METODE PENELITIAN}

Kajian ini dilakukan dengan pendekatan kepustakaan dan mengambil kasus pengembangan profesionalisme guru di Jepang sebagai faktor penting dalam menelaah peran pendidikan dalam kontribusi memecahkan persoalan bangsa ke depan yang dihadapi oleh Jepang. Masalah Jepang ke depan antara lain yang penting yaitu perkembangan teknologi dan ilmu pengetahuan yang saat ini tersaingi dengan Taiwan, China, dan Korea Selatan. Oleh karena itu Jepang mempunyai komitmen untuk meningkatkan profesionalisme guru sebagai upaya pemecahan masalah yang dihadapi.

\section{HASIL DAN PEMBAHASAN \\ Membangun Profesionalisme Guru}

Pengembangan profesi guru didorong oleh kebutuhan baik untuk memperluas atau untuk memperbaharui pengetahuan guru, keterampilan dan komitmen guru. Rangsangan untuk kebutuhan tersebut mungkin dimulai dari perubahan kurikulum, teknologi baru, kemajuan dalam pedagogi, atau semua ini. Namun, usaha yang mendasari adalah untuk meningkatkan hasil bagi siswa, apakah mereka akan difokuskan pada pemahaman, keterampilan, sikap, atau keterlibatan. Sayangnya, bagaimanapun, bukti penelitian menunjukkan bahwa, meskipun uang, waktu, dan berbagai upaya telah dilakukan untuk pengembangan profesionalisme guru, hasil yang diperoleh tidak selalu seperti yang diharapkan. Misalnya, Ingvarson, Beavis, Bishop, Peck, dan Elsworth (2004), melaporkan temuan dari studi literatur yang dilakukan, mengindikasikan bahwa, "banyak pengembangan profesionalisme guru tampaknya tidak efektif ".

$$
\text { Penelitian Weiss (2006) tentang }
$$

perubahan sistemik inisiatif berdasarkan peningkatan guru, mencatat bahwa "sesi pengembangan profesionalisme yang dirancang untuk memperdalam kebutuhan konten pengetahuan dan dukungan guru selama pelaksanaan kadang-kadang gagal mencermati konten yang dirancang untuk pengembangan profesionalisme, karena kekhawatiran guru yang lebih mendesak seperti manajemen bahan atau pedagogi". Selanjutnya, Darling-Hammond, (2009) menyatakan bahwa "relatif sedikit guru terlibat dalam kolaborasi/kerjasama intensif berkaitan dengan perencanaan peningkatan profesionalitas". Artinya bahwa jarang pihak yang berwenang melibatkan guru untuk diajak berpartisipasi dalam meningkatkan profesionalisme guru. Ada kesan bahwa 
Purwantiningsih, Ary., Suharso, Pudjo dan Ismaya, Erik Aditia

PENDIDIKAN UNTUK MEMECAHKAN MASALAH BANGSA MELALUI PENINGKATAN ...

REFLEKSI EDUKATIKA : Jurnal Ilmiah Kependidikan, Nomor 9, Volume 1, Desember 2018, hlm. 26-32

peningkatan profesionalisme guru menjadi ranah birokrasi pendidikan.

Hal ini tidak mengherankan sehingga perhatian internasional lebih diarahkan untuk mempelajari bagaimana pengembangan profesionalisme guru di Jepang melalui praktik Lesson Study di Jepang. Dalam mencari contoh sukses pengembangan profesionalisme guru, Ingvarson et al. (2004) menunjukkan bahwa hubungan antara hasil siswa dan pengembangan profesionalisme guru adalah bersifat timbal balik dalam arti bahwa "siswa lebih berhasil belajar, semakin besar kemungkinan itu adalah bahwa guru akan mengadopsi praktik yang mendorong sukses belajar lebih lanjut". Dalam nada yang sama, Royce (2010) berpendapat "apa yang kita ketahui benar bagi siswa juga berlaku dalam hal pengembangan profesionalisme guru. Artinya, bahwa guru belajar terbaik dengan melakukan dan membangun pemahaman mereka sendiri daripada diberitahu. Pengalaman menjadi pengetahuan yang sangat berharga".

Guskey (2002) mengatakan bahwa perubahan dalam pembelajaran sangat penting di mana ia menyatakan, "perbaikan biasanya hasil dari perubahan guru yang telah dilakukan dalam kelas mereka melalui praktek instruksional baru, pendekatan dan penggunaan bahan baru atau kurikulum, atau hanya modifikasi prosedur mengajar atau manajemen kelas". Dengan demikian peluang untuk bereksperimen dengan praktek kelas dan menganalisa secara rinci-yang penting dan Lesson Study Jepang dalam mengembangkan profesionalisme guru memungkinan menjadi jalan keluar untuk meningkatkan profesionalisme guru.

Hattie (2009), ketika mencari karakteristik guru yang siswa mengaku yang terbaik, mengutip Pehkonen (1992) mengatakan bahwa karakteristik termasuk "guru yang membantu siswa untuk memiliki yang berbeda dan strategi atau proses yang lebih baik untuk belajar subjek", yang mengindikasikan bahwa pengembangan profesional yang menyediakan guru dengan keterampilan ini akan menjadi manfaat bagi siswa. Seperti dibahas kemudian dalam makalah ini, lesson study pengembangan profesionalisme guru di Jepang didasarkan pada pembelajaran yang didasarkan pada penelitian pemecahan masalah terstruktur, yang merupakan bagian utama dari pembelajaran di mana siswa berbagi, berpartisipasi dan memperbaiki strategi solusi mereka dalam pendidikan sebagai instrumen untuk memecahkan masalah bangsa di masa depan.

Di Jepang peningkatan kualitas pendidikan menjadi instrumen memecahkan masalah bangsa sekaligus meraih kemajuan memang dimulai dari pengembangan profesionalisme guru. Upaya itu sebenarnya sederhana. Penelitian Lewis (2000) menuturkan bahwa para guru umumnya saling bertemu membahas isu-isu umum dan rencana pembelajaran bersama-sama. Rencana pembelajaran mungkin memiliki tema utama misal pada membangun keterampilan atau pemahaman, dan dikenal sebagai lesson research, yang diajarkan oleh seorang guru, dan diamati oleh tidak hanya semua guru yang melakukan perencanaan, tetapi juga oleh pengamat yang, di salah satu ujung spektrum, mungkin datang hanya dari sekolah guru sendiri, atau, di ujung lain, mungkin datang dari seluruh Jepang. Dalam lesson research, tersebut terdapat sesi tanya jawab mengikuti pelajaran, di mana pelajaran dibahas secara mendalam dengan modifikasi sering disarankan oleh para pengamat, termasuk seorang akademisi diundang atau pensiunan guru yang sangat berpengalaman.

Lewis (2002) menjelaskan Lesson Study Siklus memiliki empat fase: Pertama, penetapan tujuan dan perencanaan, termasuk pengembangan Rencana Pembelajaran. Kedua, mengajarkan lesson research, yang memungkinkan berkembangnya pengamatan pembelajaran. Ketiga, evaluasi pasca-pelajaran diskusi; dan Keempat, konsolidasi yang dihasilkan dari pembelajaran, yang memiliki banyak konsekuensi.

Di Jepang pengembangan profesioalisme guru terjadi di semua bidang studi dan semua tingkatan sekolah baik yang ada di pusat maupun daerah seperti pertemuan kelas, meskipun mungkin lebih umum dari beberapa daerah lain. Proses pengembangan profesionalisme guru ini di Jepang dikenal dengan sebutan "kyozaikenkyu" (Watanabe 2008). Dalam pengembangan profesionalisme guru untuk memecahkan persoalan bangsa melalui peran pendidikan ini melibatkan investigasi dan penelitian dari berbagai macam bahan ajar, termasuk buku pelajaran, materi kurikulum, rencana pelajaran dan laporan dari studi pelajaran lainnya, serta sebagai studi tentang pemahaman siswa sebelumnya, yang memungkinkan untuk guru untuk mengantisipasi reaksi siswa dan solusi untuk masalah selama 
Purwantiningsih, Ary., Suharso, Pudjo dan Ismaya, Erik Aditia

PENDIDIKAN UNTUK MEMECAHKAN MASALAH BANGSA MELALUI PENINGKATAN ...

REFLEKSI EDUKATIKA : Jurnal Ilmiah Kependidikan, Nomor 9, Volume 1, Desember 2018, hlm. 26-32

pelajaran. Sedangkan arti literal dari kyozaikenkyu adalah studi atau investigasi (Kenkyu) bahan ajar (kyozai), kata "kyoza"i berarti jauh lebih dari buku teks atau materi kurikulum dan perlu melibatkan tujuan pembelajaran. Jadi, menurut Watanabe, Takahashi dan Yoshida (2008), "kyozaikenkyu, adalah proses untuk membantu guru memperoleh pemahaman yang lebih dalam kyozai". Selain itu, penting untuk membedakan antara konten yang akan dipelajari dalam pelajaran dan tugas-tugas, karena mungkin untuk mengeksplorasi materi pelajaran yang sama dengan "kyozai" yang berbeda, atau menyelidiki subyek yang berbeda dengan "kyozai" yang sama.

Langkah seperti itu membuat para guru benar-benar mempersiapkan diri dan bertanggungjawab terhadap proses pembelajaran. Pemahaman secara mendalam yang menjadikan guru sebagai ahli (expert), bertanggungjawab (responcibility) dan mampu bekerja sama (cooperative) menjadi dasar pengembangan profesionalisme guru. Pada rangkaian berikutnya profesionalisme guru akan membentuk model pendidikan sebagai instrumen mampu memecahkan persoalan bangsa. Pendidikan pada akhirnya menjadi "panglima" kemajuan bangsa sekaligus sebagai terapi bagi masalah-masalah kebangsaan yang dihadapi.

Lebih jauh lagi peningkatan kualitas pendidikan di Jepang juga dilakukan melalui apa yang disebut sebagai research lesson. Yang dimaksud dengan research lesson menurut Lewis (2000) "are not about perfecting one lesson, but rather focus on developing teachers' ideas and experiences of different approaches to teaching. Research lessons make participants and observers think quite profoundly about specific and general aspects of teaching. Lewis and Tsuchida (1998) and Lewis (2000) identify a number of ways in which research lesson contributes to the improvement of Japanese education". (...research lesson tidak hanya tentang penyempurnaan pembelajaran, tetapi lebih focus pada pengembangan pemikiran dan pengamalan guru-guru dengan pendekatan yang berbeda dalam mengajar. Research lesson membuat para partisipan dan pengamat berfikir tentang aspek pengajaran khusus dan umum. Research lesson memberikan sumbangan bagi peningkatan kualitas pendidikan di Jepang).

Research lessons help you see your teaching from various points of view .... A lesson is like a swiftly flowing river; when you're teaching you must make judgments instantly.
When you do a research lesson, your colleagues write down your words and the students' words. Your real profile as a teacher is revealed to you for the first time ( Lewis and Tsuchida 1998).

Guskey (2002) setidaknya mencatat tiga hal yang mendorong pengembangan profesionalisme guru berhasil di Jepang dan memberikan sumbangan berarti bagi kemajuan pendidikan di Jepang. Pertama, pendidikan menawarkan para guru dan memberikan kesempatan mengembangkan keprofesionalan guru melalui komunitas guru yang kreatif, berbagi tujuan dan pengalaman, komitmen pada penemuan, selalu mempunyai usaha peningkatan kualitas dan tanggung jawab terhadap siswa maupun teman sejawat guru (education in Japan offers teachers the opportunity to develop professional communities of inquiry, with ownership of the improvement effort, a commitment to inquiry, shared goals, and a sense of responsibility to their colleagues and students) (Lewis et al 2009).

Kedua, sekalipun kemajuannya lambat namun proses pengembangan professional guru tetap berlangsung dengan mengembangkan berbagai komponen pendidikan seperti kolaborasi perencanaan pembelajaran, dan sebagainya (while progress is often slow at the start, the process can evolve over time with teachers beginning by weaving "some of the simpler components of education such as collaborative lesson planning in with their existing practices, and only later ...grasping the significance of other ideas such as developing a lesson rationale and documenting their own learning"). Ketiga, pendidikan di Jepang memberikan peluang bagi para guru untuk membangun profesionalisme atas usaha dan pemahaman terhadap diri sendiri. (education in Japan enables teachers to build on their efforts and refine their understandings. In the case reported by Lewis et al. (2009), teachers on their own initiative decided to continue to meet to further revise their lesson to allow colleagues to observe the research lesson and collect data. This is not an uncommon occurrence in Japan education.

Terakhir sebagaimana ditunjukkan Perry and Lewis (2009) dalam komentarnya, pengalaman pengembangan profesionalisme guru di Jepang "may stand a better chance of survival than specific instructional reforms because it is a means for bringing practice into line with goals that can be used flexibly to support various reform ideas". 
Purwantiningsih, Ary., Suharso, Pudjo dan Ismaya, Erik Aditia

PENDIDIKAN UNTUK MEMECAHKAN MASALAH BANGSA MELALUI PENINGKATAN ...

REFLEKSI EDUKATIKA : Jurnal Ilmiah Kependidikan, Nomor 9, Volume 1, Desember 2018, hlm. 26-32

Inti dari kemajuan pendidikan di Jepang yang dapat dijadikan sarana untuk memecahkan masalah bangsa Jepang di masa mendatang adalah memperbaiki profesionalistas guru melalui pengembangan profesionalisme guru. Memang itu bukan satu-satunya cara, namun langkah Jepang melakukan perbaikan pendidikan dengan reformasi profesionalitas guru telah menjadi acuan bagi pengembangan pendidikan di banyak Negara. Jikalau pendidikan dapat memberikan kontribusi bagi pemecahan masalah bangsa di masa depan, maka perbaikan profesionalitas guru menjadi suatu keniscayaan.

\section{Bagaimana Pendidikan di Indonesia ?}

Sosok pendidikan Indonesia masa depan yang mampu eksis menghadapi masalah masa depan di tengah perubahan dan globalisasi adalah pendidikan yang mampu mengadopsi berbagai perubahan yang tengah berlangsung. Unesco memberikan gambaran pendidikan masa depan dicirikan dengan beberapa hal yaitu 1) berfokus pada pemupukan potensi unggul setiap peserta didik, 2) keseimbangan beragam kecerdasan (intelektual, emosional, sosial, spritual, kinestetis.), 3) mengajarkan life skills, 4) sistem penilaiannya berbasis portofolio dari hasil karya siswa/mahasiswa, 5) pembelajaran berbasis kehidupan nyata dan praktik di lapangan, 6) Guru/dosen lebih berperan sebagai motivator dan fasilitator agar peserta didik mengembangkan minatnya masing-masing, 7) pembelajaran didasarkan pada kemampuan, cara/gaya belajar, dan perkembangan psikologis peserta didik masing-masing.

Karakter pendidikan masa depan dengan ciri-ciri tersebut menuntut dunia pendidikan harus memiliki kredibilitas organisasi kelembagaan secara utuh dan menyeluruh. Sistem ini harus memiliki akuntabilitas yang tinggi terhadap masyarakat, menunjukkan efisiensi dalam operasionalnya, menghasilkan lulusan yang berkualitas, memiliki manajemen internal yang transparan dan memenuhi standar. Dalam ranah individual, semua pemangku pendidikan haruslah merupakan individual (sumber daya manusia) yang unggul dan mampu mengungguli semua tuntutan perubahan yang dihasilkan oleh globalisasi.

Untuk menjawab tantangan dan tuntutan pendidikan masa depan, pemerintah telah mengeluarkan kebijakan pendidikan berupa Peraturan Presiden (Perpres) No. 8 tahun 2012 Tentang Kerangka Kualifikasi Nasional Indonesia di mana kurikulum pendidikan harus mengacu kearah KKNI yang saat ini ramai dibicarakan. Dalam waktu yang terbatas ini saya tidak akan membahas tentang KKNI, namun secara singkat KKNI sebenarnya merupakan kebijakan pendidikan yang berkaitan dengan 8 misi Rencana Pembangunan Jangka Panjang Nasional (RPJPN) 2005-2025 dan menghasilkan lulusan pendidikan (Learning Output) yang maju, mandiri, adil, dan makmur disertai dengan kualifikasi standar nasional, regional dan internasional agar dapat bersaing secara global.

Dalam perspektif dan pemikiran saya, dunia pendidikan, tak terkecuali pendidikan tinggi akan dapat eksis menghadapi tantangan dan tuntutan global apabila mampu mengembangkan strategi pengembangan pendidikan yang mencakupi 1) Mengedepankan model perencanaan pendidikan tinggi partisipatif yang berdasarkan pada need assessment dan karakteristik masyarakat. Partisipasi masyarakat dalam perencanaan pendidikan tinggi merupakan tuntutan yang harus dipenuhi, 2) Penguatan fokus pendidikan, yaitu fokus pendidikan tinggi diarahkan pada pemenuhan kebutuhan masyarakat, kebutuhan stakeholders, kebutuhan pasar dan tuntutan teman saing, 3) Pemanfaatan sumber luar (out sourcing), memanfaatkan berbagai potensi sumber daya (belajar) yang ada, lembaga-lembaga pendidikan yang ada, pranatapranata kemasyarakatan, perusahaan/industri, dan lembaga lain yang sangat peduli pada pendidikan tinggi, 4) Memperkuat kolaborasi dan jaringan kemitraan dengan berbagai pihak, baik dari instansi pemerintah mapun non pemerintah, bahkan baik dari lembaga di dalam negeri maupun dari luar negeri, 5) Menciptakan soft image pada masyarakat sebagai masyarakat yang gemar belajar, sebagai masyarakat belajar seumur hidup, dan 6) Pemanfaatan teknologi informasi untuk mengakses berbagai informasi dalam mengembangkan potensi diri baik institusi maupun individu dan lingkungannya (misal; penggunaan internet, multi media pembelajaran, sistem informasi terpadu, dsb).

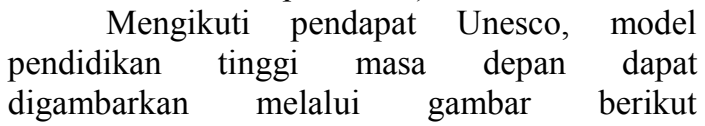




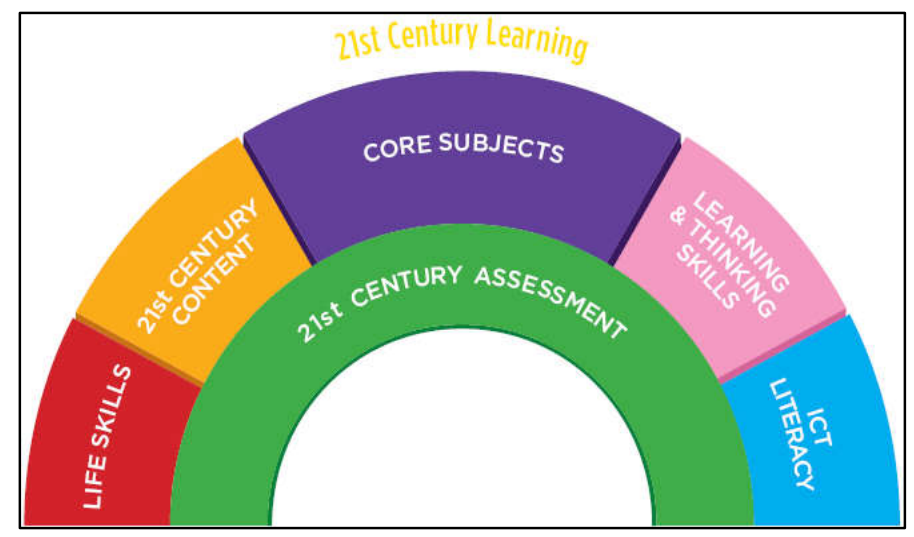

Setidaknya terdapat 5 (lima) unsur yang harus dikembangkan dalam pendidikan masa depan yakni 1) keterampilan berkehidupan, 2) isi/materi pembelajaran, 3) mata kuliah inti, 4) keterampilan belajar dan berfikir, 5) serta melek ICT. Elaborasi dari konsep model pendidikan masa depan yang dikembangkan Unesco dalam pembelajaran dapat dirumuskan melalui pengembangan kurikulum yang isi dan dan subtansi materi perlu mencakup kelima hal tersebut. Tentu menjadi tantangan dan peluang tersendiri bagi dunia pendidikan di negeri ini, khususnya pemdidikan tinggi dalam mewujudkan model pendidikan masa depan.

Berkolaborasi, bersinergi, dan berkoordinasi dengan para pemangku kepentingan pendidikan nampaknya merupakan langkah yang harus dilakukan oleh pengelola pendidikan. Termasuk didalamnya yang berkaitan pendanaan yang seringkali membuat para pengelola dunia pendidikan harus frustasi dan memeras otak untuk mencukupi pengelolaan pendidikan.

Konsekuensi dan tantangan pendidikan tinggi masa depan tidak perlu dihindari, tetapi harus dihadapi dengan suatu optimisme bahwa dibalik konsekuensi dan tantangan itu selalu ada peluang yang dapat dilakukan sehingga tetap survive. Kata orang bijak "If there is a will, theres a way", atau "everybody is the architect of his own future", maka dunia pendidikan tak terkecuali pendidikan tinggi harus selalu mewujudkan komitmen untuk tetap terus bergerak maju karena selalu terbentang jalan untuk menapak masa depan lebih baik.

\section{SIMPULAN}

Banyak langkah untuk dapat memecahkan persoalan yang dihadapi suatu bangsa di masa depan. Namun hampir semua bangsa sepakat bahwa pendidikan merupakan sarana penting untuk memecahkan berbagai masalah bangsa. Pendidikan menjadi faktor strategis bagi pemecahan masalah. Jepang sebagai salah satu Negara yang mempunyai rating tinggi dalam kemajuan pendidikan percaya bahwa kunci peningkatan kualitas pendidikan sebagai sarana memecahkan persoalan bangsa melalui peningkatan dan pengembangan profesionalisme guru. Upaya pengembangan profesionalisme guru di Jepang ini telah menjadi lesson study bagi berbagai negara untuk memajukan pendidikan. Indonesia sebenarnya telah menempuh jalan yang sama untuk memajukan pendidikan, namun sayangnya belum ditangani secara serius.

\section{DAFTAR PUSTAKA}

Guskey, R. T. 2002. Professional development and teacher change. Teachers and Teaching: Theory and Practice, 8(3/4), 381-91.

Harwell, S. 2013. Teacher Professional Development: It's Not an Event, It's a Process. Texas: CORD Pub.

Hattie, J. 2009. Visible Learning: A synthesis of over 800 meta-analyses relating to achievement. London: Routledge.

Ingvarson, L., Beavis, H., Bishop, A. J., Peck, R., \& Elsworth, G. 2004. Investigation of effective mathematics teaching and learning in Australian secondary schools. Canberra, ACT: Australian Government Department of Education, Science and Training. 
Purwantiningsih, Ary., Suharso, Pudjo dan Ismaya, Erik Aditia PENDIDIKAN UNTUK MEMECAHKAN MASALAH BANGSA MELALUI PENINGKATAN ... REFLEKSI EDUKATIKA : Jurnal Ilmiah Kependidikan, Nomor 9, Volume 1, Desember 2018, hlm. 26-32

Janes, R. 2010. Japan Perspective. Tokyo: OECD.

Lewis, C. 2002. A handbook of teacher-led instructional change. Philadelphia: Research for Better Schools.

Lewis, C., and Tsuchida, I. 1998. A lesson is like a swiftly flowing river: Research lessons and the improvement of Japanese education. American Educator, 14-17 \& $50-52$

Perry, R. R., \& Lewis, C. C. 2009. What is successful adaptation of Lesson Study in the U.S.? Journal of Educational Change, $10(4), 365-391$.

Royce, C. 2010. A revolutionary model of professional development. Science Scope, $34(3), 6$.
Stigler, J. W., \& Hiebert, J. 1999. The teaching gap: Best ideas from the world's teachers for improving education in the classroom. New York: Summit Books.

Suharso, P. 2011. Pendidikan Masa Depan, Makalah Semnas, Jember.

Suyanto, 2000. Pendidikan di Indonesia. Yogyakarta: LKiS.

Watanabe, T., Takahashi, A., \& Yoshida, M. 2008. Kyozaikenkyu: A critical step for conducting effective lesson study and beyond. In F. Arbaugh \& P. M. Taylor (Eds.), Inquiry into mathematics teacher education. Association of Mathematics Teacher Educators (AMTE) Monograph Series (Volume 5, pp. 131-142). San Diego, CA: Association of Mathematics Teacher Educators. 